\title{
Preformulation of a liquid dosage formulation of captopril for pediatric use: drug-excipient compatibility and stability studies
}

\author{
Janaina da Silva Goes ${ }^{1}$, Fátima Duarte Freire ${ }^{2}$, Túlio Flávio Accioly de Lima e Moura ${ }^{1,2}$, \\ Cícero Flávio Soares Aragão ${ }^{1,2}$, Fernanda Nervo Raffin ${ }^{\circledR 1,2, *}$
}

\begin{abstract}
${ }^{1}$ Postgraduate Program in Pharmaceutical Sciences (PPgCF), Department of Pharmacy, Federal University of Rio Grande do Norte (UFRN), Natal-RN, Brasil, ${ }^{2}$ Postgraduate Program in Development and Technological Innovation on Pharmaceuticals (PPgDITM), Federal University of Rio Grande do Norte (UFRN), Natal-RN, Brasil
\end{abstract}

\begin{abstract}
Currently, medications used in children are typically modified from pharmaceutical dosage forms designed for adults. Captopril is widely adapted to liquid formulations for use in hospitals. Its stability in the aqueous medium is reduced since it undergoes oxidation producing captopril disulfide (its main metabolite). The aim of this formulation study was to suggest favorable conditions for the development of a stable captopril formulation. The compatibility between the drug and excipients was evaluated by differential scanning calorimetry analysis (DSC). For studies in solution, different formulations were prepared according to a factorial design varying EDTA concentration, water purity and $\mathrm{pH}$. The resultant formulations were stored at $60^{\circ} \mathrm{C}$ and analyzed over a twelve-day period using HPLC. The DSC curves obtained suggested, although not conclusive to elucidation, interactions of captopril with citric acid and sucralose. The stability study of these solutions revealed that the variables significantly influenced captopril content, which degraded at zero order kinetics and rates differing by a factor of up to 7 times, where $\mathrm{pH}$ proved the most influential factor. Interactions between variables were observed. Therefore, development of a stable captopril formulation is feasible provided EDTA and a buffering agent is used at suitable concentrations $(0.08 \%$ and $\mathrm{pH} 3.85)$.
\end{abstract}

Keywords: Pediatric Formulation. Captopril/pharmacokinetics. Thermal Analysis. Degradation Kinetics. Drug Stability. Drug Compounding/ utilization. Drug Utilization. Excipients/ pharmacokinetics. Dosage Forms. Drug Dosage Calculations. Kinetics. Enzyme Stability/drug effects.

\section{INTRODUCTION}

The available medications are mostly developed for adults. Thus, the data on safe dose is often extrapolated for pediatric use. Children are subjected to therapy risk because they have different pharmacokinetic and pharmacodynamic mechanisms according to age and compared to adults (Rosa et al., 2006; OMS, 2007; Jadhav, Kern, 2010). The lack of accurate and adequate information on the use of pediatric medicines or the lack of appropriate formulations for the indicated dosages led to the spread of the term "therapeutic orphans" when referring to children (Permala et al., 2010).

Thus, non-specific medicines for children can be classified as off-label, used with a different age,

\footnotetext{
*Correspondence: F. N. Raffin. Dept de Farmácia, UFRN. Av. General Gustavo Cordeiro de Farias, s/n, Petrópolis, 59.010-180, Natal-RN, Brasil. Phone: 55843342 2327. E-mail: feraffin@ufrnet.br
}

dose, frequency, presentation, other delivery route or indication to label guidelines (Carvalho et al., 2003; Rose, 2005; Costa, Lima, Coelho, 2009); or unapproved, when contraindicated or not licensed for use in children, manipulated or modified in the hospital, and with no specific dosage for children (Carvalho et al., 2003).

In various studies, captopril, an inhibitor of angiotensin converting enzyme (ECA) (Ferreira, 1998; Katzung, 2005), was cited as a necessary medicament in liquid form for the treatment of childhood arterial hypertension and heart failure (Peterlini, Chaud, Pedreira, 2003; Standing, Tuleu, 2005; Flores-Pérez, 2008; Santos et al., 2008; Costa, Lima, Coelho, 2009; Costa, Rey, Coelho, 2009). The problem of childhood hypertension has only received greater attention, so few medications have been developed and tested on children. Therefore, the antihypertensive treatment is initiated at dosages based on data obtained for adults (Salgado, Carvalhaes, 2003; Flynn, 2008). 
The development of a liquid formulation of captopril for pediatric use is challenging owing to its susceptibility to oxidative degradation facilitated by high humidity and catalyzed by metal traces commonly found in excipients (Marcatto et al., 2005). Moreover, these preparations must provide safe excipients and good palatability, as the medications mostly have a bitter, sour or salty taste (Hempenstall, Tuleu, 2009).

Matthew, Das Gupta (1996) demonstrated that co-solvents, chelating agents and high concentrations of captopril favored the drug's stability in aqueous systems. Schlatter, Sola, Saulnier (1997) evaluated the effect of $\mathrm{pH}$ and temperature on the stability of solutions at $1 \mathrm{mg} / \mathrm{mL}$ prepared from a captopril tablet of $25 \mathrm{mg}$. The solution prepared in citrate buffer at $\mathrm{pH} 5.0$ was stable for at least 30 days at $4{ }^{\circ} \mathrm{C}$. In extemporaneous oral liquid formulations at the same concentration containing antioxidants and chelating agents, $\mathrm{pH}$ did not influence the stability of captopril. However, samples stored at low temperatures were more stable and presented better microbiological quality (Escribano Garcia et al., 2005). Furthermore, studies have shown that a $\mathrm{pH}$ value in the acidic range and the addition of chelating agents (e.g. EDTA) retard the oxidation of captopril (BergerGryllaki, 2007; Kristensen et al., 2008; Brustugun et al., 2009).

Different conclusions arise from studies carried out under diverse conditions suggesting the influence of the factors on each other is complex. In this way, experimental planning such as factorial design has been applied as a powerful tool to understand the impact of formulation variables and preparation conditions on the stability and other properties of drug dosage forms (Padamwar, Pokharkar, 2006; Cekić et al., 2015). Besides, thermal analysis has been useful in pre-formulation studies to evaluate interactions between drug and excipients (Freire et al., 2009; Oliveira et al., 2011).

Given that liquid preparation obtained by adapting the pharmaceutical dosage form (grinding of tablets followed by dispersion in a liquid medium) may result in inaccurate dosages and inadequate stability, jeopardizing the treatment, the aim of the present study was to evaluate the influence of interactions between $\mathrm{pH}$, water quality and chelating agent concentration on the stability of captopril in the preparation of a pediatric formulation.

\section{MATERIAL AND METHODS}

\section{Raw materials and solvents}

- Captopril (Galena Química e Farmacêutica Ltda);
- $\quad$ EDTA (Isofar - Indústria e Comércio de Produtos Químicos Ltda);

- Anhydrous citric acid and dihydrate sodium citrate (Labsynth);

Sucralose (Embrafarma Pharmaceutical Expertise); Distilled water;

- Mineral water of the Indaiá brand (Composition: Chloride $=23.80 \mathrm{mg} . \mathrm{L}^{-1}$; Sodium $=14.99 \mathrm{mg} . \mathrm{L}^{-1}$; Nitrate $=2.9 \mathrm{mg} . \mathrm{L}^{-1} ;$ Bicarbonate $=0.80 \mathrm{mg} \cdot \mathrm{L}^{-1}$; Sulfate $=0.8 \mathrm{mg} . \mathrm{L}^{-1} ;$ Potassium $=0.79 \mathrm{mg} \cdot \mathrm{L}^{-1}$; Magnesium $=0.76 \mathrm{mg} . \mathrm{L}^{-1}$; Calcium $=0.23 \mathrm{mg} \cdot \mathrm{L}^{-1}$; Barium $=0.027 \mathrm{mg} . \mathrm{L}^{-1}$; Strontium $=0.006 \mathrm{mg} . \mathrm{L}^{-1}$ );

- For the preparation of the mobile phase used in the HPLC analysis: Methanol HPLC grade (VETEC Fine Chemicals Ltd), Phosphoric Acid 85\% (Isofar - Industry and Chemicals Ltd) and ultra-pure water.

\section{Study in solid phase (powder)}

Determination of the drug-excipient compatibility

The compatibility between captopril and the excipients (EDTA, citric acid, dihydrate sodium citrate and sucralose) was measured by differential scanning calorimetry (DSC). The samples were obtained by physically mixing the drug and excipients at a proportion of $1: 1(\mathrm{~m} / \mathrm{m})$ with a spatula.

The DSC curves were obtained on a Shimadzu DSC-60 device, using aluminum pans with $2 \mathrm{mg}$ of samples under atmospheric pressure of $\mathrm{N}_{2}$ at a flow rate of $50 \mathrm{~mL} \cdot \mathrm{min}^{-1}$, heating rate of $10^{\circ} \mathrm{C} \cdot \mathrm{min}^{-1}$ and temperature range of between 25 and $400^{\circ} \mathrm{C}$.

In addition to the thermal analysis by DSC, the thermal behavior of captopril was evaluated by differential thermal analysis (DTA) and thermogravimetry (TG). Approximately $4 \mathrm{mg}$ of the drug were placed in an alumina pan and analyzed on a Shimadzu DTG-60 device under an atmosphere of nitrogen at a flow rate of $50 \mathrm{~mL} \cdot \mathrm{min}^{-1}$, heating rate of $10^{\circ} \mathrm{C} \cdot \mathrm{min}^{-1}$ and temperature range of between 35 and $900{ }^{\circ} \mathrm{C}$. Both devices were calibrated with indium standards (melting point at $156^{\circ} \mathrm{C}$ ) and zinc (melting point at $420^{\circ} \mathrm{C}$ ).

\section{Studies in liquid phase}

\section{Experimental design and statistical analysis}

The formulations were developed using the minimum and maximum allowable concentration of EDTA, 0.005 and $0.1 \%(\mathrm{~m} / \mathrm{v})$, respectively -1 and +1 levels, according to the Handbook of Pharmaceutical Excipients, 6th ed. (Rowe, Sheskey, Quinn, 2009), in two types of water (distilled as lower level or -1 , and mineral 
- the highest level or +1$)$ and at three $\mathrm{pH}$ values $(2.5,4.0$ and 5.5 , corresponding to levels $-1,0$ and +1 respectively). Therefore, $2^{2} \times 3$ factorial planning was used, giving a total of 12 formulations, each in triplicate, with a final volume of $500 \mathrm{~mL}$. The resultant formulations are shown in Table I. Captopril concentration was fixed at $5 \mathrm{mg} / \mathrm{mL}$.

Furthermore, sucralose was added to the formulations as a sweetener, at variable concentrations according to the $\mathrm{pH}$. The concentrations used were determined according to the subjective sensory analysis, where higher concentrations of the sweetener were required in more acidic formulations. The solutions were then subjected to heating in a QUIMIS oven (MODEL: Q-317 B252) at $60{ }^{\circ} \mathrm{C} \pm 2{ }^{\circ} \mathrm{C}$ and analyzed in alternate days for 12 days.

Captopril was quantified according to the methodology contained in the Brazilian Farmacopeia, i.e. by high-performance liquid chromatography in a Shimadzu chromatograph, equipped with LC-10AT pump, ultraviolet detector (SPD-M20A5), DGU-20A5 degasser and PERKIN ELMER column with length of $250 \mathrm{~mm}$ and an internal diameter of $4.6 \mathrm{~mm}$, packed with silica chemically bonded to an octadecylsilane group $(5 \mu \mathrm{m})$, kept at ambient temperature and mobile phase flow rate of $1 \mathrm{~mL} \cdot \mathrm{min}^{-1}$. The mobile phase consisted of a mixture of phosphoric acid $0.11 \%(\mathrm{v} / \mathrm{v})$ and methanol (45:55), filtered through an ALLCROM nylon membrane filter with pore size of $0.22 \mu \mathrm{m}$ (Farmacopeia ..., 2010).

The influence of the factors on the captopril content as a function of time was examined with the aid of the software Statistica 7.0, through Pareto diagrams $(p=0.05)$; marginal means for analysis of interactions between factors; and response surface graphs, from which the best combination of factors to develop a stable formulation was established.

\section{Evaluation of the degradation kinetics}

Initially, captopril content data obtained over the 12-day test period were plotted using Microsoft Excel 2010 software to determine the order of the reaction. Data on the slope inclination, intercept and values of the coefficient of determination $\left(\mathrm{R}^{2}\right)$ were derived from the equations applied for the zero, first and second order reactions (Florence, Attwood, 2003). Thus, the values of captopril content as a function of time were used, considering a direct linear relationship to zero order, the logarithmic function of the content versus the time to the first order, and in the case of the second order, inverse values of content as a function of time. The coefficients of determination $\left(\mathrm{R}^{2}\right)$ derived were compared, considering the order of the reaction corresponding to the function for which the highest values were obtained.

Half-life $\left(\mathrm{t}_{1 / 2}\right)$ time and the time taken for degradation of $10 \%$ of the drug $\left(\mathrm{T}_{90 \%}\right)$ were also calculated, being defined as the validity period of the solution (Florence, Attwood, 2003).

\section{RESULTS AND DISCUSSION}

\section{Studies in solid phase}

Determination of the drug-excipient compatibility The DSC, TG and DTA curves of captopril and DSC

TABLE I - Formulations combining variables at different levels submitted to stress testing at $60{ }^{\circ} \mathrm{C}$

\begin{tabular}{ccccc}
\hline Formulation & [EDTA]\% & Type of water & pH & [Sucralose]\% \\
\hline Control & - & Distilled & 2,73 & - \\
$\mathrm{Fa}$ & 0.005 & Distilled & 2.5 & 0.20 \\
$\mathrm{Fb}$ & 0.005 & Distilled & 4.0 & 0.17 \\
$\mathrm{Fc}$ & 0.005 & Distilled & 5.5 & 0.15 \\
$\mathrm{Fd}$ & 0.1 & Distilled & 2.5 & 0.20 \\
$\mathrm{Fe}$ & 0.1 & Distilled & 4.0 & 0.17 \\
$\mathrm{Ff}$ & 0.1 & Distilled & 5.5 & 0.15 \\
$\mathrm{Fg}$ & 0.005 & Mineral & 2.5 & 0.20 \\
$\mathrm{Fh}$ & 0.005 & Mineral & 4.0 & 0.17 \\
$\mathrm{Fi}$ & 0.005 & Mineral & 5.5 & 0.15 \\
$\mathrm{Fj}$ & 0.1 & Mineral & 2.5 & 0.20 \\
$\mathrm{Fk}$ & 0.1 & Mineral & 4.0 & 0.17 \\
$\mathrm{Fl}$ & 0.1 & Mineral & 5.5 & 0.15 \\
\hline
\end{tabular}


binary mixtures with the excipients used in this study are depicted in Figure 1.

The DSC curve and the DTA of captopril (Figure 1a) shows an endothermic event with a peak at $111.83{ }^{\circ} \mathrm{C}$ $\left(\Delta \mathrm{H}_{\text {melting }}=-135.24 \mathrm{~J} \cdot \mathrm{g}^{-1}\right)$, corresponding to the melting of the drug. A second event starts around $200{ }^{\circ} \mathrm{C}$ and is related to drug decomposition. The TG curve shows that the decomposition occurs between 170 and $449^{\circ} \mathrm{C}$, in two steps, with a $97.21 \%$ decrease in the initial mass.

In mixtures A (figure 1b) and C (Figure 1d), the thermal events for each substance alone were observed. Moreover, the enthalpy of the first peaks of mixtures A $\left(\Delta \mathrm{H}_{\text {melting }}=-58.52 \mathrm{~J} \cdot \mathrm{g}^{-1}\right)$ and $\mathrm{C}\left(\Delta \mathrm{H}_{\text {melting }}=-64.74 \mathrm{~J}_{\mathrm{g}} \mathrm{g}^{-1}\right)$ corresponded to approximately half the value of the melting peak of the drug, confirming the absence of interaction between captopril and excipients used in these mixtures: EDTA and dehydrate sodium citrate.

In mixture B (Figure 1c), the captopril melting point was reduced to $104.53{ }^{\circ} \mathrm{C}$ with broadening of the corresponding peak while the thermal event related to citric acid melting was not observed. However, the amount of energy involved in the captopril melting process (the first event observed on DSC curve of binary mixture) close to the value of the enthalpy involved in the melting of captopril $\left(\Delta \mathrm{H}=-82.28 \mathrm{~J} \cdot \mathrm{g}^{-1}\right)$ indicates no interaction between the components. Therefore, the DSC curve for mixture B suggests the dissolution of the citric acid in the molten captopril (Oliveira et al., 2011).

The DSC curve of the binary mixture between captopril and sucralose (Figure 1e) exhibited an exothermic event at $124{ }^{\circ} \mathrm{C}$ and $\Delta \mathrm{H}=29.64 \mathrm{~J} \mathrm{~g}^{-1}$ while the thermal event related to sucralose at this temperature is endothermic $\left(\Delta \mathrm{H}_{\text {melting }}=-74.01{\mathrm{~J} . \mathrm{g}^{-1}}^{-1}\right)$ characteristic of the melting of the substance. This change suggests an interaction between these components or dissolution of sucralose in the molten captopril.

Thermal analysis alone was not conclusive to elucidate if interactions between captopril and both citric acid and sucralose took place. Other methods should be used such as Infrared Spectrophotometry to understand the influence of those components in the solid state. Moreover, the results of the stress test provided later indicate that sucralose and citric acid were not determining factors for the decrease in captopril stability in the solutions.

\section{Studies in liquid phase}

\section{Evaluation of stability of captopril solutions at $5 \mathrm{mg} / \mathrm{mL}$}

The 12 formulations were subjected to the stress test and the captopril content was monitored by HPLC for a 12-day period (peak at 4.0 minutes). A gradual decrease in captopril content was observed. According to Figure 2, the formulations with the lowest $\mathrm{pH}$ values ( $\mathrm{Fe}, \mathrm{Fg}, \mathrm{Fj}$ and $\mathrm{Fk}$ ) showed less variation in captopril content over the 12 days. Moreover, the Fc formulation stands out for the significant decrease in captopril content, showing poor stability. This solution was prepared at higher $\mathrm{pH}$ (5.5) and low concentrations of EDTA in distilled water, where these conditions appear to be the most unfavorable for the preparation of a stable oral solution of captopril.

In agreement with this observation, from the fourth day of analysis, the emergence of a peak can be noted on the chromatograms $\left(t_{r}=6.2 \mathrm{~min}\right.$, probably captopril disulfide), a phenomenon most evident in the samples of the formulations at $\mathrm{pH} 5.5$ (Fc, Ff, $\mathrm{Fi}$ and $\mathrm{Fl}$ ).

In general, the formulations at $\mathrm{pH} 4.0$ showed minor variations in captopril content, as did formulations at the same $\mathrm{pH}$ value containing the highest concentration of EDTA.

When calculating the coefficient of determination $\left(\mathrm{R}^{2}\right)$ for reactions of zero, first and second order, the predominance of zero-order reactions was observed for all formulations together with the highest $\mathrm{R}^{2}$ values (Table II). Moreover, the $\mathrm{R}^{2}$ values were lower than the expected value (0.99), particularly in formulations with mineral water, probably due to the presence of ionic species in these solutions that can interact with metals able to accelerate the degradation of captopril (Pierangeli et al., 2001).

Thus, in contrast to results reported by BergerGryllaki et al. (2007), Kristensen et al. (2008) and Mathew, Das Gupta (1996), the rate of the decomposition reaction proved independent of captopril concentration, where the limiting factor, in this case, may have been temperature, as the formulations were stored in an oven at $60^{\circ} \mathrm{C}$.

For a zero-order reaction, $t_{1 / 2}$ and $t_{90 \%}$ are calculated by the equations 1 and 2 respectively:

$$
\begin{gathered}
t_{1 / 2}=\frac{C_{0}}{\left(2 * k_{0}\right)} \\
t_{90 \%}=\frac{\left(0,1 * C_{0}\right)}{k_{o}}
\end{gathered}
$$

(equation 1)

(equation 2)

where $\mathrm{C}_{0}$ is the initial concentration and $\mathrm{k}_{0}$ is the slope. The values of $\mathrm{k}_{0}$ correspond to the percentage of drug that is degraded with time (or degradation rate) and the intercept of the line at $\mathrm{t}=0$ is equal to the initial concentration.

The values of the degradation constant, half-life and shelf-life are shown in Table II. Analysis of these parameters confirms that formulations with a higher 

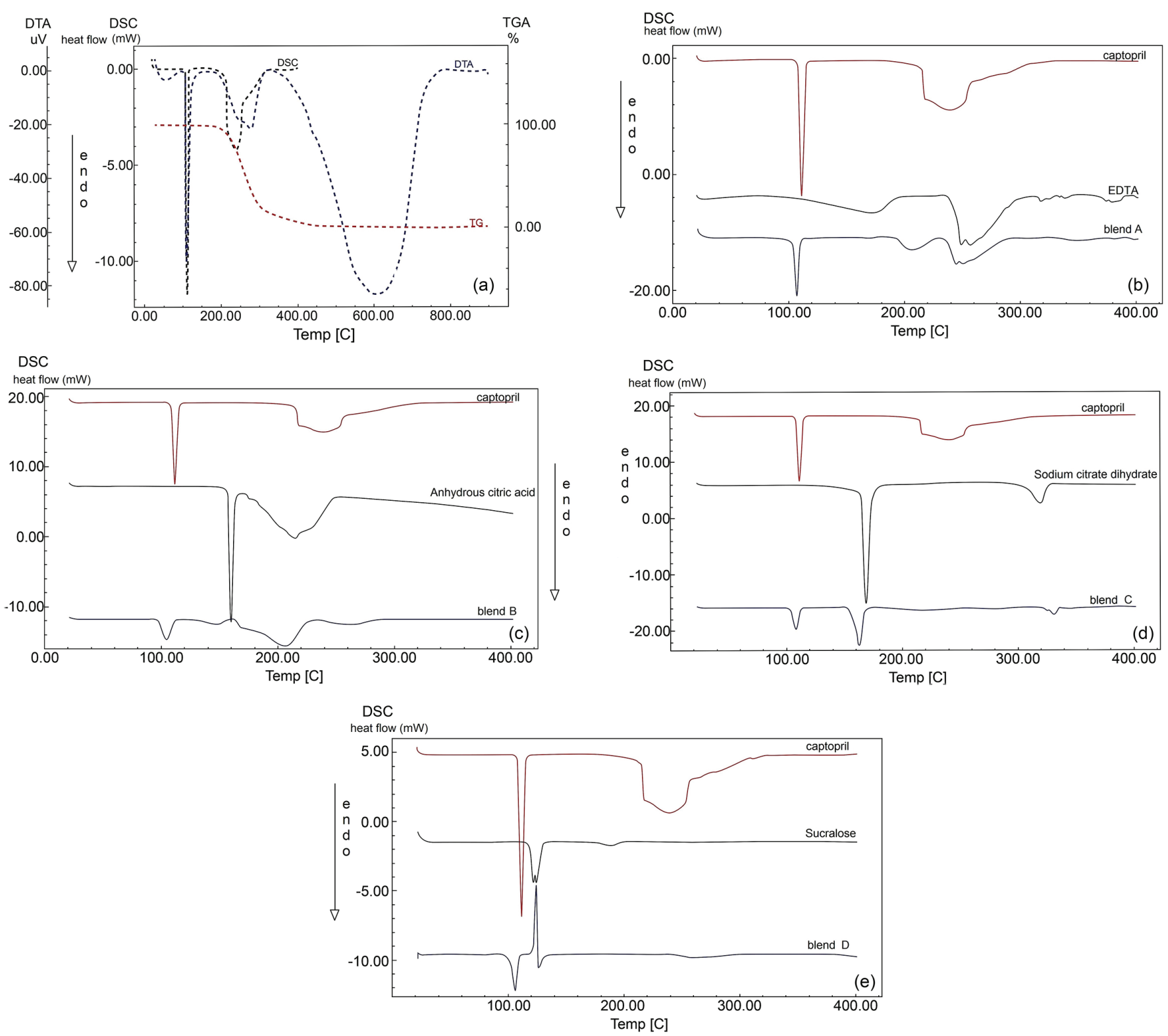

FIGURE 1 - DSC, TG DTA and captopril curves (a) and DSC curves of excipients and their respective binary mixtures with the drug (b: EDTA and mixture A; $\mathbf{c}$ : citric acid and mixture B; $\mathbf{d}$ : dihydrate sodium citrate and mixture C; and e: sucralose and mixture D).

$\mathrm{pH}$ value (Fc, Ff, Fi and Fl) are less stable, showing degradation of 1.7 to 3.6 times faster than captopril alone.

On the other hand, formulations prepared using mineral water as the solvent at $\mathrm{pH} 2.5$ and $4.0(\mathrm{Fg}, \mathrm{Fh}$, $\mathrm{Fj}$ and $\mathrm{Fk}$ ) resulted in less degradation than formulations prepared with distilled water. The Fk formulation (prepared with $0.1 \%$ of EDTA in mineral water at $\mathrm{pH}$ 4.0) showed a lower rate of decomposition, resulting in higher stability of up to 15 days. The worst and best formulations concerning degradation rate ( $\mathrm{Fc}$ and Fk respectively) differed by a factor of about 7 times. Kristensen et al. (2008) showed that captopril aqueous solutions at $5 \mathrm{mg} / \mathrm{mL}$ containing EDTA were more stable than those prepared at $1 \mathrm{mg} / \mathrm{mL}$. The values found for $\mathrm{t}_{90 \%}$ were 46 and 7 days respectively at $25^{\circ} \mathrm{C}$. At temperature conditions closer to that used in this study, the degradation of captopril at $5 \mathrm{mg} / \mathrm{mL}$ resulted in constants around $9 \times 10^{-3}$ days $^{-1}$ at $\mathrm{pH}$ values below 4 (Timmins, Jackson, Wang, 1982).

No evidence was found that sucralose influences captopril stability. Sucralose concentration was much lower in the solutions compared to the rate used in solid state study. Also, the solutions with higher sucralose concentration were those with lowest $\mathrm{pH}$ value, the higher stability provided was attributed to $\mathrm{pH}$. 


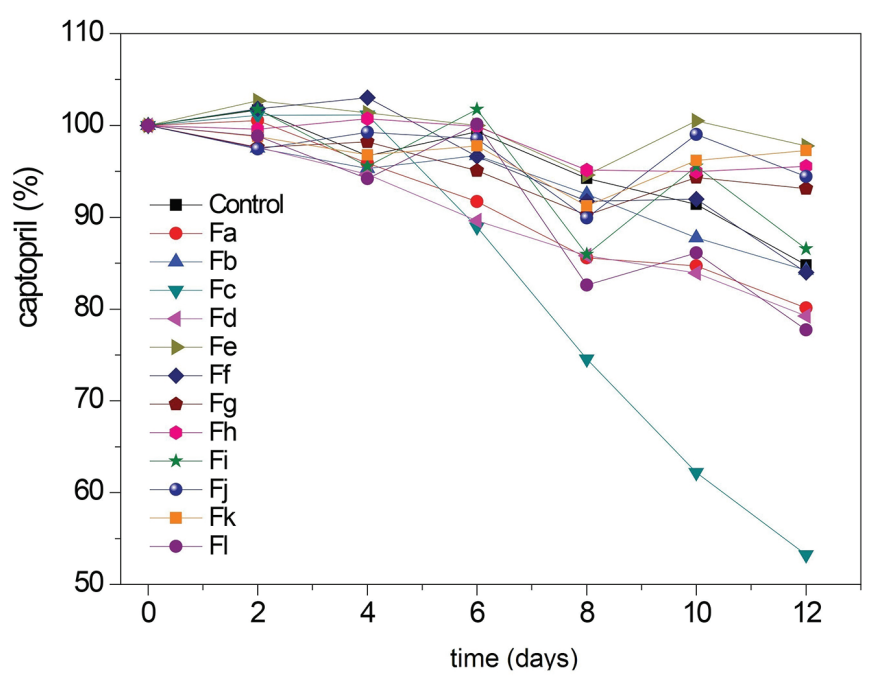

FIGURE 2 - Captopril content in the formulations submitted to $60{ }^{\circ} \mathrm{C}$ over the 12 -day period.

Evaluation of the influence of $\mathrm{pH}$, EDTA concentration and type of water on captopril content and interaction between factors

The influence of each variable, as well as their interactions, on captopril content are shown in a Pareto chart (Figure 3). The chart shows that $\mathrm{pH}$ influenced captopril content both positively and negatively. This is because captopril is a diprotic acid with $\mathrm{pKa}$ values of 3.7 and 9.8 relating to the carboxyl and thiol groups, respectively. Therefore, $\mathrm{pH}$ values above 3.7 promote ionization of the molecules, rendering them more reactive. However, degradation at a $\mathrm{pH}$ below 4.0 is independent of $\mathrm{pH}$, where according to the Henderson-Hasselbalch equation, the thiol group is hardly ionized (Timmins, Jackson, Wang, 1982).

The type of water positively influenced captopril content probably due to the presence of different ionic species. The mineral water may have favored the stability of the compositions due to lower activity of metallic ions able to catalyze the oxidation of captopril, as they compete for the exchange site (Pierangeli et al., 2001).

The presence of metallic ions, such as iron and copper, increases the rate of oxidation of captopril since they act as catalysts in the oxidation reaction of the thiol group. These ions are contaminants usually found in the formulation excipients, packaging, caps and/or manufacturing equipment. For this reason, the EDTA is an interferent with a significant positive contribution to stability because it acts by sequestering metallic ions, as opposed to leaving them free to favor the degradation reaction of captopril (Timmins, Jackson, Wang, 1982).

Furthermore, the interaction between the factors is significant, since the influence of a specific variable depends on the level of the other, an effect seen in Figure 4. Thus, the assessment of interactions between the EDTA concentration and the other variables confirms that raising the concentration of the chelating agent enhances the stability of solutions only when the other conditions are unfavorable, i.e. $\mathrm{pH} 5.5$ and using distilled water. Therefore, for different levels of the water type variable, the concentration of the chelator has a different influence

TABLE II - Linear regression coefficient values for zero order kinetic $\left(\mathrm{R}^{2}\right)$, degradation rate $\left(\mathrm{k}_{0}\right)$, half-life time $\left(\mathrm{t}_{1 / 2}\right)$ and validity $\left(\mathrm{t}_{90 \%}\right)$ of the analyzed formulations

\begin{tabular}{ccccc}
\hline Formulation & $\mathrm{R}^{2}$ & $\mathrm{k}_{0}\left(\%\right.$. day $\left.^{-1}\right)$ & $\mathrm{t}_{1 / 2}($ days $)$ & $\mathrm{t}_{90 \%}($ days $)$ \\
\hline Control $^{*}$ & 0.8112 & 1.22 & 40.8 & 8.2 \\
$\mathrm{Fa}$ & 0.9619 & 1.81 & 27.6 & 5.5 \\
$\mathrm{Fb}$ & 0.9031 & 1.24 & 40.2 & 8.0 \\
$\mathrm{Fc}$ & 0.9018 & 4.37 & 11.4 & 2.3 \\
$\mathrm{Fd}$ & 0.9903 & 1.76 & 28.4 & 5.7 \\
$\mathrm{Fe}$ & 0.7074 & 0.72 & 69.2 & 13.8 \\
$\mathrm{Ff}$ & 0.9151 & 2.48 & 20.2 & 4.0 \\
$\mathrm{Fg}$ & 0.8251 & 0.75 & 67.0 & 13.4 \\
$\mathrm{Fh}$ & 0.7751 & 0.70 & 71.3 & 14.3 \\
$\mathrm{Fi}$ & 0.8789 & 2.07 & 24.1 & 4.8 \\
$\mathrm{Fj}$ & 0.7691 & 0.66 & 75.2 & 15.1 \\
$\mathrm{Fk}$ & 0.7009 & 0.64 & 77.7 & 15.5 \\
$\mathrm{Fl}$ & 0.9395 & 2.45 & 20.4 & 4.1 \\
\hline
\end{tabular}

*captopril in aqueous solution (distilled water) 


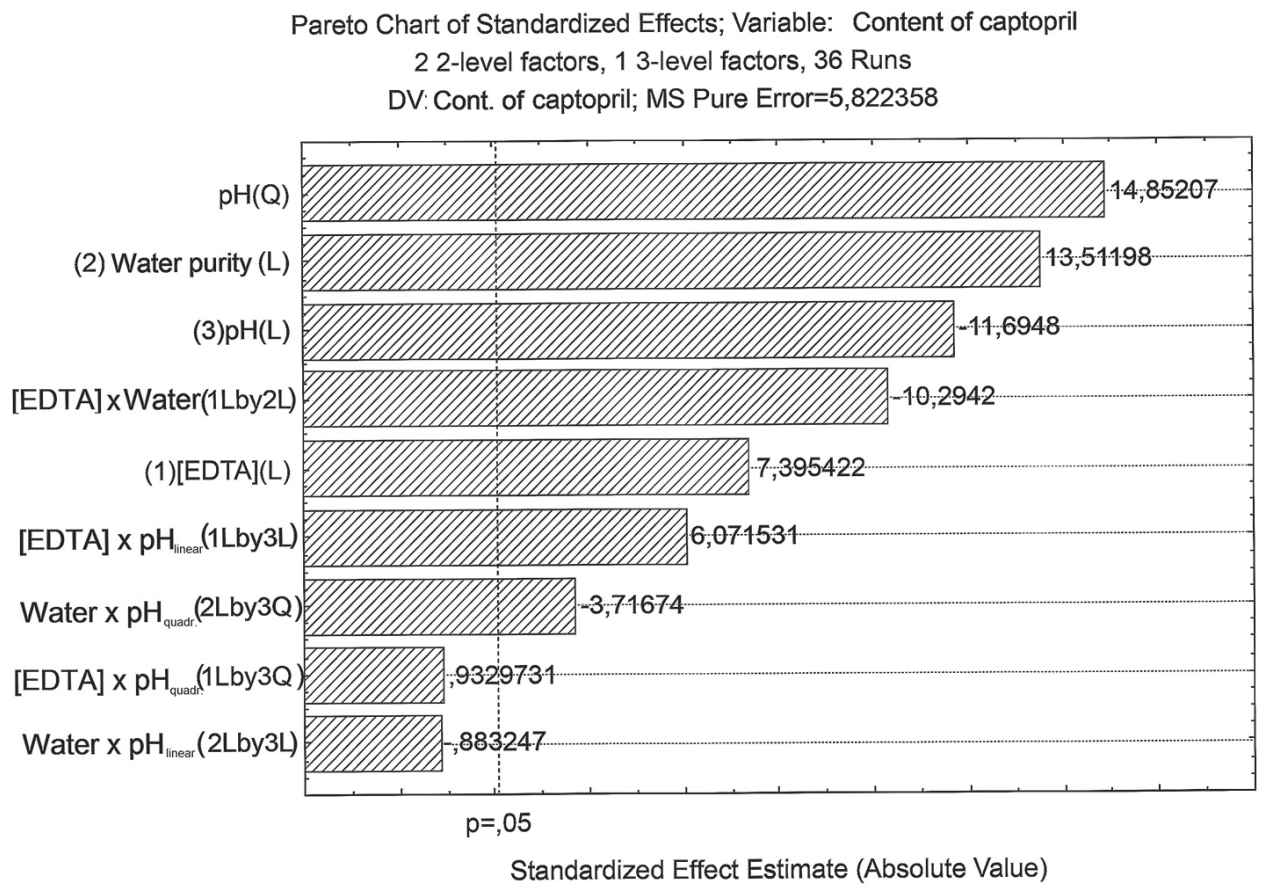

FIGURE 3 - Pareto diagram of standardized effects of $\mathrm{pH}$, type of water and EDTA concentration on the captopril degradation process.

on the stability of the solution, showing the interaction between these factors (1Lby2L).

Regarding the relationship between water and $\mathrm{pH}$, the type of water proved critical for the stability of the solutions at lowest $\mathrm{pH}$ values (2.5).

The surface response graphs (Figure 5) allow the optimal areas for the stability of captopril to be established. Figure 5 a shows that a formulation with a $\mathrm{pH}$ near the central range of between 3.7 and 4.0, associated with an EDTA concentration of between $0.0525 \%$ and $0.1 \%$, with the loss of at most $10 \%$ of captopril may be obtained.

The optimum point in the surface response graph to the type of water $x$ concentration of EDTA (Figure $5 b)$ is shifted to mineral water. Therefore, if mineral water associated with an EDTA concentration above $0.0525 \%$ is used, there will be a smaller loss of captopril (maximum 10\%). This result support the possibility of interaction of the ionic species in the mineral water with the metallic ions, once the chelating agent can be used in the low level. Meanwhile, extremes values of $\mathrm{pH}$ in the range studied (2.5 or 5.5) associated with distilled water favor the captopril degradation, being more evident in the higher $\mathrm{pH}$ range (Figure 5c), i.e. the central zone of the graph comprises an area of lesser degradation of captopril ( $90 \%$ content).

From the data on surface responses, it can be stated that to develop a stable formulation of captopril, EDTA at a concentration of $0.08 \%(\mathrm{~m} / \mathrm{v})$ and buffering agents (anhydrous citric acid and sodium citrate dihydrate) must be added to obtain a formulation with an approximate $\mathrm{pH}$ of 3.85. The indicated values correspond to the average values of the ranges in which higher stability of captopril was achieved.

\section{CONCLUSIONS}

Experimental planning was a useful tool to the pre-formulation study for the development of a liquid formulation of captopril. From the results of captopril contents obtained through the stress test, it can be stated that $\mathrm{pH}$ is the factor that has the most influence on the stability of the solutions. The type of water also has a significant influence, where mineral water improved the stability of captopril. Among these three factors, the concentration of EDTA has an important function in preserving the captopril content when associated with other interferents.

The surface response graphs revealed the components and their optimal concentrations required to maintain the stability of captopril, data which may be used in the development of future formulations for pediatric use. Based on the results of the response surface graphs it can be concluded that a solution containing $0.08 \%(\mathrm{~m} / \mathrm{v})$ of EDTA at a pH of 3.85 can be considered the basis for a more stable formulation of captopril. 
2 2-level factors, 13 -level factors, 36 Runs

NOTE: Std.Errs. for means computed from MS Error $=5,822358$
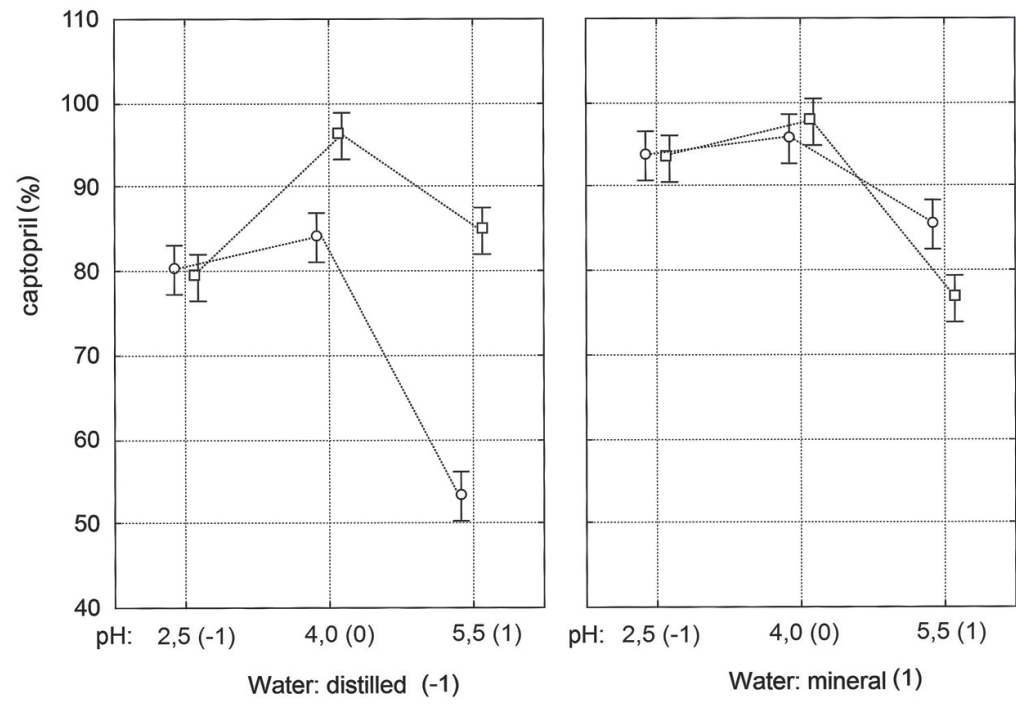

a)

[EDTA]

모 0,005\% (-1)
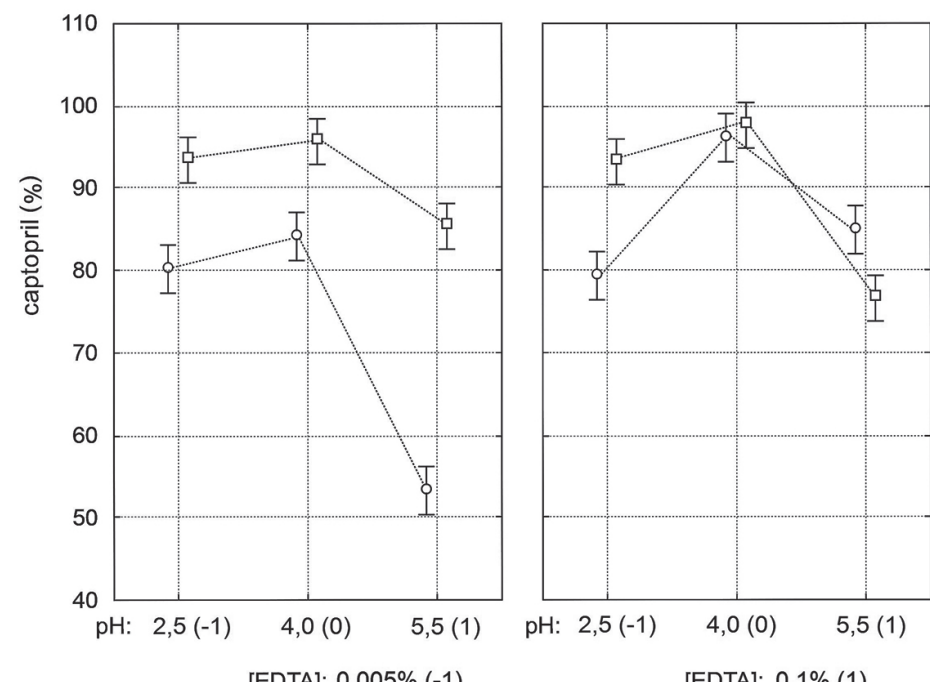

푹.. 0,1\% (1)

b)

water purity

포 distilled (-1)

도.. mineral (1)

[EDTA]: $0,005 \%(-1)$

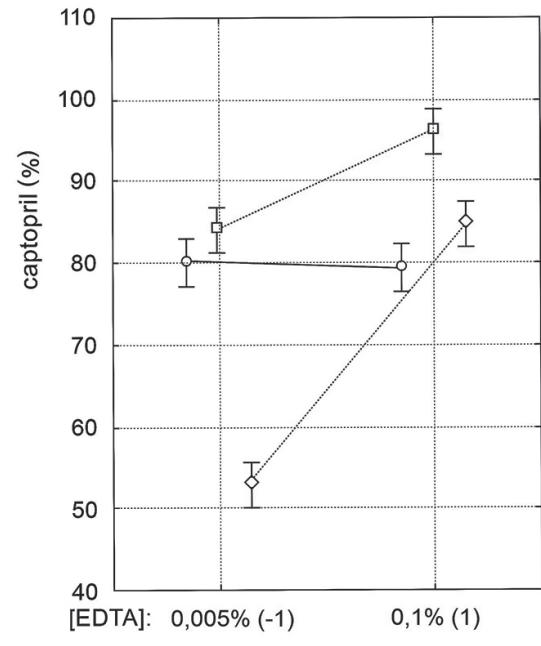

Water: distilled $(-1)$
[EDTA]: $0,1 \%(1)$

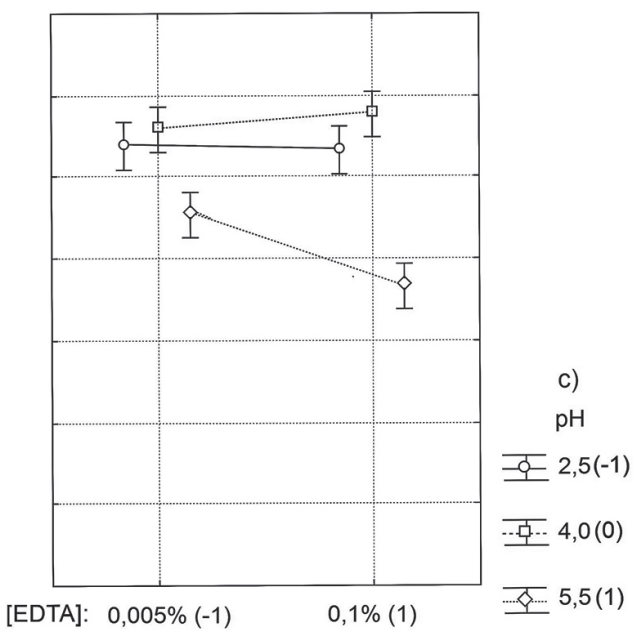

Water: mineral (1)

FIGURE 4 - Marginal means with confidence intervals (95\%) for captopril content at different levels of the variables interfering the captopril degradation process: (a) EDTA; (b) water purity; (c) pH. 


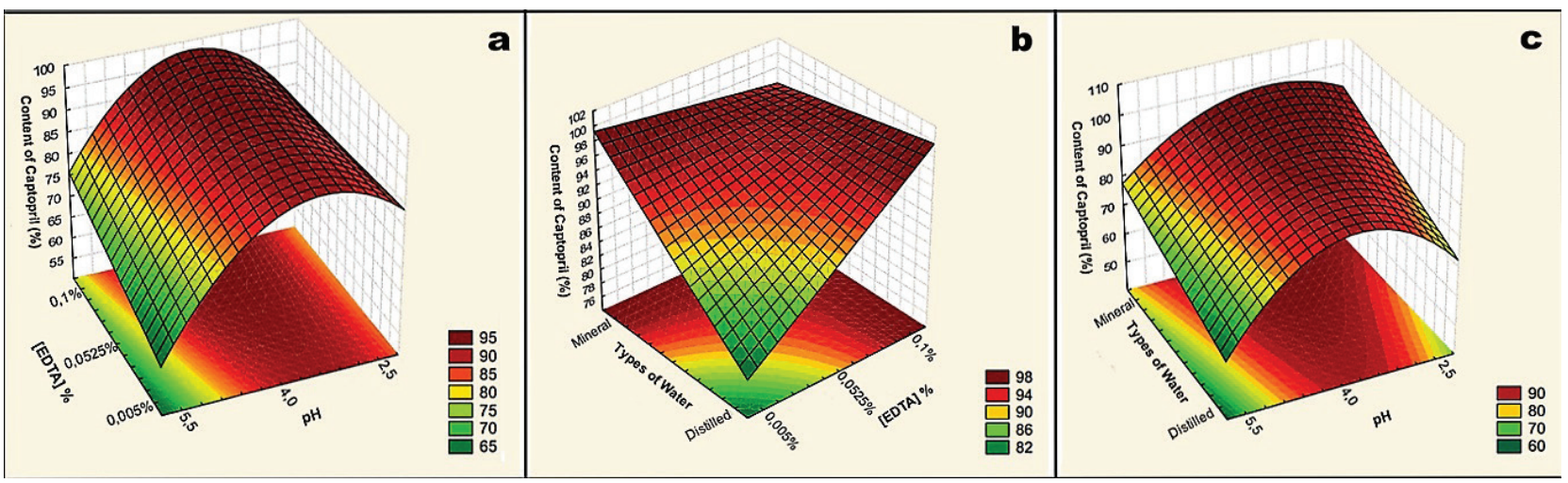

FIGURE 5 - Surface Response for a) pH $x$ EDTA; b) type of water $x$ EDTA c) type of water $x$ pH.

\section{ACKNOWLEDGMENTS}

This work was supported by the CAPES/MEC through a Master`s fellowship.

\section{REFERENCES}

Berger-Gryllaki M, Podilsky G, Widmer N, Gloor S, Testa B, Pannatier A. The development of a stable oral solution of captopril for paediatric patients. Eur J Hosp Pharm Sci. 2007;13(3):27-32.

Brustugun J, Lao YE, Fagernaes C, Braenden J, Kristensen S. Long term stability of extemporaneously prepared captopril oral liquids in glass bottles. Am J Health-Syst Pharm. 2009;66(19):1722-5.

Carvalho PRA, Carvalho CG, Alievi PT, Martinbiancho J, Trotta EA. Identificação de medicamentos "não apropriados para crianças" em prescrições de unidade de tratamento intensivo pediátrica. J Pediatr. 2003;79(5):397-402.

Cekić ND, Đorđević SM, Savić SR, Savić SD. A full factorial design in the formulation of diazepam parenteral nanoemulsions: physicochemical characterization and stability evaluation. Adv Technol. 2015;4(1):69-77.

Costa PQ, Lima JES, Coelho HLL. Prescrição e preparo de medicamentos sem formulação adequada para crianças: um estudo de base hospitalar. Braz J Pharm Sci. 2009;45(1):57-66.

Costa PQ, Rey LC, Coelho HLL. Lack of drug preparations for use in children in Brazil. J Pediatr. 2009;85(3):229-35.

Escribano Garcia MJ, Torrado Durán S, Torrado Durán JJ. Stability study of an aqueous formulation of captopril at $1 \mathrm{mg} /$ mL. Farm Hosp. 2005;29(1):30-6.
Farmacopeia Brasileira. 5.ed. Brasília: Anvisa/Fundação Osvaldo Cruz; 2010.

Ferreira SH. Aspectos históricos da hipertensão: do fator de potenciação da bradicinina (BPF) aos inibidores da ECA. HiperAtivo. 1998;5(1):6-8.

Florence AT, Attwood D. Princípios físico-químicos em farmácia. São Paulo: Edusp; 2003.

Flores-Pérez C, Flores-Pérez J, Juárez-Olguín H, BarrancoGarduño LM. Frequency of drug consumption and lack of pediatric formulations. Acta Pediatr Mex. 2008;29(1):16-20.

Flynn JT. Hypertension in the young: epidemiology, sequelae and therapy. Nephrol Dial Transplant. 2008;24(1):370-5.

Freire FD, Aragão CFS, Moura TFAL, Raffin F. Compatibility study between chlorpropamide and excipients in their physical mixtures. J Therm Anal Calorim. 2009;97:355-7.

Hempenstall J, Tuleu C. Meeting commentary - formulating better medicines for children. Int J Pharm. 2009;379:143-5.

Jadhav PR, Kern SE. The need for modeling and simulation to design clinical investigations in children. J Clin Pharmacol. 2010:50(9 suppl):121S-9S.

Katzung BG. Farmacologia básica \& clínica. 9.ed. Rio de Janeiro: Guanabara Koogan; 2005.

Kristensen S, Lao YE, Brustugun J, Braenden JU. Influence of formulation properties on chemical stability of captopril in aqueous preparations. Pharmazie. 2008;63(12):872-7.

Marcatto A P, Lamim R, Block L C, Bresolin T M B. Análise de cápsulas de captopril manipuladas em farmácia. Rev Ciênc Farm Básica Apl. 2005;26(3):221-5. 
Mathew M, Das Gupta V. The stability of captopril in aqueous systems. Drug Stab. 1996;1(3):161-5.

Oliveira MA, Yoshida MI, Gomes ECL. Análise térmica aplicada a fármacos e formulações farmacêuticas na indústria farmacêutica. Quim Nova. 2011;34(7):1224-30.

OMS. Promover la Seguridad de los Medicamentos para Niños, 2007. [Accessed at: 2016 May 20]. Available from: http:// whqlibdoc.who.int/publications/2007/9789241563437_spa.pdf.

Padamwar MN, Pokharkar VB. Development of vitamin loaded topical liposomal formulation using factorial design approach: drug deposition and stability. Int J Pharm. 2006;320(1/2):37-44.

Permala J, Hassali MA, Awaisu A, Shafie AA. Dosing information in a standard drug reference: are pediatrics still therapeutically neglected? Pediatr Int. 2010;52(2):290-5.

Peterlini MAS, Chaud MN, Pedreira MLG. Órfãos de terapia medicamentosa: a administração de medicamentos por via intravenosa em crianças hospitalizadas. Rev Latino-Am Enfermagem. 2003;11(1):88-95.

Pierangeli MAP, Guilherme RLG, Oliveira RL, Curi N, Silva MLN. Efeito da força iônica da solução de equilíbrio sobre a adsorção/dessorção de chumbo em Latossolos brasileiros. Pesq Agropec Bras. 2001;36(8):1077-84.
Rosa MLSD, Albuquerque MIC, Oliveira MFT. Medicamentos e pediatria. Bol. CIM (Ordem dos Farmacêuticos), 2006:1-2.

Rose K. Better medicines for children - where are we now, and where do we want to be? Br J Clin Pharmacol. 2005(59):657-9.

Rowe RC, Sheskey PJ, Quinn ME, editors. Handbook of pharmaceutical excipients. 6.ed. London: Pharmaceutical Press; 2009. 917p.

Salgado CM, Carvalhaes JTA. Hipertensão arterial na infância. J Pediatr. 2003;79(supl 1):115-24.

Santos DB, Clavenna A, Bonati M, Coelho HLL. Off-label and unlicensed drug utilization in hospitalized children in Fortaleza, Brazil. Eur J Clin Pharmacol. 2008(64):1111-8.

Schlatter J, Sola A, Saulnier JL. Stabilité d'une solution orale de captopril $1 \mathrm{mg} / \mathrm{mL}$. J Pharm Clin. 1997;16(2):125-8.

Standing JF, Tuleu C. Pediatric formulations: getting to the heart of the problem. Int J Pharm. 2005;300(1/2): 56-66.

Timmins P, Jackson IM, Wang YJ. Factors affecting captopril stability in aqueous solution. Int J Pharm. 1982;11(4):329-36.

Received for publication on $05^{\text {th }}$ January 2018 Accepted for publication on $28^{\text {th }}$ May 2018 